\title{
THE EFFECTS OF TOP PRUNING ON GROWTH AND PRODUCTION OF CONELETS AND CONES IN PINUS BRUTIA TEN SEED ORCHARDS OF DIFFERENT AGES
}

\author{
UTJECAJ PRIKRAĆIVANJA NA RAST I UROD ČEŠERČIĆA \\ I ČEŠERA VRSTE PINUS BRUTIA TEN U SJEMENSKIM \\ PLANTAŽAMA RAZLIČITE DOBI
}

\author{
Murat ALAN1', Rumi SABUNCU², Turgay EZEN², Selim KAPLAN³
}

\begin{abstract}
Summary
In economic and biological terms (rapid growth, the ability to produce seeds at an early age, etc.) Pinus brutia Ten. is one the most important forest tree species in Turkey. Considerable progress has been made in Pinus brutia Ten. breeding program and both phenotypical and according to the results of progeny trials, totaling 615-hectare seed orchardshas been established. Pinus brutia Ten. seed orchardshas reached $43 \%$ of the total orchard area and covered the largest area.

To acquire information on the management of seed orchards, top pruning has been carried out on three Pinus brutia Ten. seed orchards of different ages (old, middle-aged and young). Two top pruning regimes were applied in these three seed orchards, once in 2008 to the old orchard, while a single topping regime was applied in 2008 and 2012 to the middle-aged and young orchards.Each year, the height, diameter at breast height, and bi-directional crown diameter were measured, and all conelets and cones on ramets were counted beforeand after pruning.

At the end of four years, control ramets in old and young seed orchards had higher values of height, diameter at breast height, and volume indexcompared to the middle-aged orchard. On the other hand, even though the control ramets in the middle-aged seed orchard reached a greater height, pruned ramets reached a greater volume index and diameter at breast height. While the height differences observed between control and pruned ramets in all seed orchards at the beginning eventually decreased, it was observed that the heights of pruned ramets grew proportionally larger.

No difference was founded between the control and pruned ramets in terms of cone and conelet production. Pruning intervals and regimes varied in old, middle-aged and young seed orchards, and it was acknowledgedthat top pruning could be used for old, middle-aged and young seed orchard managements.
\end{abstract}

KEY WORDS: Turkish red pine, breeding, seed production, seed orchard management, afforestation

\footnotetext{
${ }^{1}$ Dr. sc. Murat Alan, Department of Forest Engineering, Faculty of Forestry, Karabuk University, 78050 Karabuk, Turkey, muratalan@karabuk.edu.tr

${ }^{2}$ Msc, Rumi Sabuncu, Regional Directorate of Forestry, 07010 Muratpasa, Antalya, Turkey rumisabuncu@gmail.com

${ }^{3}$ Forest engineer, Turgay Ezen tezen@ortohum.gov.tr, dr. sc. Selim Kaplan sskap39@gmail.com, Forest Tree Seeds and Tree Breeding Research Directorate 06560 Yenimahalle, Ankara, Turkey
} 


\section{INTRODUCTION} UVOD

Seed orchards serve as the link between tree breeding and afforestation (Kang 2001, Funda and El-Kassaby 2012). First planned tree breeding activities began in Turkey in 1964 (Urgenc 1967). In these studies, pine species were given priority, and the acquired knowledge and experience led to the establishment of the first commercial seed orchard for Turkish red pine (Pinus brutia Ten.) species in 1976 (Alan 2012).

Turkish red pine is the most important coniferous tree among the forest tree species of Turkey. It is a characteristically fast-growing and widely distributed species, also the most commonly used species in wood production and afforestation in Turkey. In this respect, it has also been defined as one of the preferred and prioritized species for tree breeding in the National Tree Breeding Program, which was first implemented in 1994 (Koski and Antola 1993). The aim of this Breeding Program is to use seed orchards to meet the seed requirements of afforestation activities. In this context, since the first seed orchard was established in 1976, the total area of Turkish red pine seed orchards has reached 615 hectares, 75 hectares of which were established through progeny trials (Bilgen et al. 2013; Oatiam 2015).

Seed orchards are considered to be an affordable tool that allows forest areas - and hence the quantity of forest products - to be increased over time (Codesido and Fernandez-Lopez 2014). Seed orchard management comprises various practices employed at seed orchards to produce the genetically and physiologically high-quality seeds that are necessary for establishing forests (Bramlett 1991; Codesido and Fernandez-Lopez 2014). While various tools can be used in seed orchard management, top pruning is a management tool that enables the relatively easy and safe collection of seed by reducing the heights of trees (Matheson and Willcocks 1976; Kajba et al. 2007; Funda and ElKassaby 2012; Miller and DeBell 2013).

Top pruning which is the practice of removing whole tops or large branches by cutting reduces the heights of individual trees at a seed orchard, allowing them to receive more light. The greater amount of light received by ramets increases the ratio of Carbon: Nitrogen, which in turn increases the level of seed production (Sweet 1975). Top pruning may also facilitate tasks such as seed collection, pest control, and supplemental pollination activities (Gerwig 1987; Stoehr et al. 1995; Almqvist and Jansson 2015).

As Turkish red pine has been the most widely used species for afforestation in Turkey, Turkish red pine seed orchards have always been given the highest priority and importance. To collect information on the efficient management of Turkish red pine seed orchards,to date a number of studies have been conducted on top pruning (Sengun and Semerci 2002) and $\mathrm{GA}_{4 / 7}($ Gibberellic acid) application (Ozturk et al. 2005).
In Turkey, seed orchards are still being established based on the results of progeny trials, and this leads to the constant formation of young seed orchards (Alan 2012). There are no studies on the effect of pruning on young and middleaged Turkish red pine seed orchards.

While seed production naturally begins when the Turkish red pine seed orchards are seven-year-old, seed collection becomes more difficult in the ensuing years as the heights of the trees increases. An investigation of cone and seed production data over ten-year periods revealed that seed production per hectare in Turkish red pine seed orchards begins to decline after 20 years (Alan et al. 2011). This decrease is thought to be caused by two underlying reasons: Firstly, as the ramets in the seed orchard become fully developed, their branches cover all the empty spaces, decreasing the quantity of light the trees receive, and thus reducing the quantity of seed produced. Secondly, even though seed production levels remain relatively high, the increasing heights of the trees gradually makes it more difficult to collect the cones, preventing all the cones from being harvested, resulting in a certain quantity of cones being left on the trees. It has been suggested that severe and heavy top pruning (where more than four years growth is cut) might be a solution when it becomes difficult to collect cones due to the excessive growth of the trees in a seed orchard (Stoehr et al. 1995; Smith 2004). Alan et al. (2011) reported that by 2008 , the area of Turkish red pine seed orchards aged 15 years or older had reached 75\% of the total seed orchard. This has led to a need to examine the effects of intense top pruning on seed orchards aged 15 years or more. To enhance the diminishing cone production in middle-aged and old Turkish red pine seed orchards, information is required on the effects of top pruning in young orchards. In this context, study was implemented in 2008 on old, middle-aged and young seed orchards. As a continuation of that study, top pruning was repeated in middle-aged and young seed orchards in 2012, while the old seed orchard was not pruned.

This study aimed to (a) asses the development (height, diameter at breast height and volume index) of pruned and unpruned ramets, (b) compare pruned and unpruned ramets in terms of conelet, which is considered immature cone, and cone, which contains seeds for reproduction of species productivity, and (c) use the obtained information on productivity and ramet development for the management of seed orchards.

\section{MATERIALS AND METHODS} MATERIJALI I METODE

Three Turkish red pine seed orchards with different age groups (young, middle-aged and old orchards) were included in this study (Table 1). When the study was initiated in 2008 , seed production had not yet begun in young seed 
Table 1. Researched Turkish red pine seed orchards.

Tablica 1. Istraživane klonske sjemenske plantaže brucijskoga bora.

\begin{tabular}{|c|c|c|c|c|c|c|c|}
\hline $\begin{array}{l}\text { National No } \\
\text { Nacionalni br. }\end{array}$ & $\begin{array}{l}\text { Name } \\
\text { Naziv }\end{array}$ & $\begin{array}{c}\text { Area } \\
\text { Područje }\end{array}$ & $\begin{array}{l}\text { Number of } \\
\text { clones } \\
\text { Broj klonova }\end{array}$ & $\begin{array}{l}\text { Spacing } \\
\text { Razmak }\end{array}$ & $\begin{array}{c}\text { Year of } \\
\text { Establishment } \\
\text { Godina osnivanja }\end{array}$ & $\begin{array}{c}\text { Latitude (N) Longtitude (E) } \\
\text { Geografska širina } \\
\text { Geografska duljina }\end{array}$ & $\begin{array}{l}\text { Altitude } \\
\text { Nadmorska } \\
\text { visina }\end{array}$ \\
\hline 37 & Akcay & 17.2 & 30 & $8 \times 8$ & 1992 & $\begin{array}{l}36^{\circ} 38^{\prime} 51^{\prime \prime} \\
29^{\circ} 18^{\prime} 07^{\prime \prime}\end{array}$ & 250 \\
\hline 166 & Kasaba & 5.3 & 73 & $5 \times 5$ & 2000 & $\begin{array}{l}36^{\circ} 27^{\prime} 07^{\prime \prime} \\
29^{\circ} 43^{\prime} 40^{\prime \prime}\end{array}$ & 290 \\
\hline 180 & Serinyol & 3.4 & 91 & $5 \times 5$ & 2004 & $\begin{array}{l}36^{\circ} 22^{\prime} 09^{\prime \prime} \\
36^{\circ} 13^{\prime} 21^{\prime \prime}\end{array}$ & 100 \\
\hline
\end{tabular}

Table 2. Pruning ages, regimes and times applied in the studied seed orchards Tablica 2. Dob, režimi i vrijeme orezivanja u sjemenskim plantažama

\begin{tabular}{|c|c|c|c|c|c|c|}
\hline $\begin{array}{l}\text { National No } \\
\text { Nacionalni br. }\end{array}$ & $\begin{array}{l}\text { Name } \\
\text { Naziv }\end{array}$ & $\begin{array}{l}\text { First pruning age } \\
\text { Starost biljke za } \\
\text { vrijeme prvog } \\
\text { orezivanjae }\end{array}$ & $\begin{array}{c}\text { Pruning dose } \\
\text { Intenzitet orezivanja }\end{array}$ & $\begin{array}{l}\text { Second pruning age } \\
\text { Starost biljke za } \\
\text { vrijeme drugog } \\
\text { orezivanja }\end{array}$ & $\begin{array}{c}\text { Pruning dose } \\
\text { Stupanj orezivanja }\end{array}$ & $\begin{array}{c}\text { Pruning time } \\
\text { Vrijeme orezivanja }\end{array}$ \\
\hline 180 & Serinyol & 4 & $\begin{array}{l}\text { terminal shoot } \\
\text { terminalni izbojak }\end{array}$ & 8 & $\begin{array}{l}\text { terminal shoot } \\
\text { terminalni izbojak }\end{array}$ & $\begin{array}{l}\text { March } \\
\text { ožujak }\end{array}$ \\
\hline 166 & Kasaba & 8 & $\begin{array}{l}1 \text { node } \\
1 \text { nodij }\end{array}$ & 12 & $\begin{array}{l}1 \text { node } \\
1 \text { nodij }\end{array}$ & $\begin{array}{l}\text { March } \\
\text { ožujak }\end{array}$ \\
\hline 37 & Akcay & 16 & $\begin{array}{c}3 \text { and } 5 \text { nodes } \\
\text { 3. i } 5 . \text { nodij }\end{array}$ & - & - & $\begin{array}{l}\text { March } \\
\text { ožujak }\end{array}$ \\
\hline
\end{tabular}

orchard, while it had recently begun in middle-aged, and had been ongoing for nine years in old seed orchard. While the middle-aged and young seed orchards were established at $5 \times 5$ spacing, the old seed orchard was established at the $8 \times 8$ spacing generally used in Turkish red pine seed orchard.

In the young seed orchard, the terminal shoots were pruned, while in the middle-aged seed orchard, the top nodes which are the points on stem originating branches were pruned. The same treatment was applied in these seed orchards in 2012. On the other hand, in the old seed orchard, three and five nodes were pruned in 2008, and no pruning was performed in 2012 (Table 2).

In all three seed orchards, a randomized complete block design with five blocks was used. In each block, $7 \times 7$ pruned and unpruned ramets were taken randomly, the outer 2 rows were kept as buffer, and 9 ramets $(3 \times 3)$ in the middle were included into the study. The heights of the ramets were measured before and after pruning, and the diameter at breast height and crown diameter were then measured bidirectionally.

A year after pruning, all conelets and cones were counted, and the height, diameter at breast height and crown diameter values were all measured in nine ramets at the center of all pruned and unpruned plots. Measurements and observations continued for two in the old seed orchards, and for four years in the young and middle-aged seed orchards. Conelet and cone numbers were transformed logarithmically before the analysis of variance. Furthermore, assum- ing that the top volume of each ramets has a conic shape, the volume index was calculated using the formula $V=r^{2} \pi h / 3$. In the formula, $V$ represents the volume index, $\boldsymbol{r}$ represents the crown radius, and $\boldsymbol{h}$ represents the height of the tree. Volume index and diameter at breast height were used as covariates in the model.

The statistical model for the analysis of variance is given below:

$y i j k l=\mu+A_{1} D_{i j k l}+A_{2} \cdot V_{i j k l}+B_{i}+T_{j}+z_{k}+T z_{j k}+e_{i j k l}$

$Y_{i j k l}$ : the observed value for tree $l$, in block $i$, at treatment $j$, of year $k$,

$\mu$ : general mean,

$A_{1}$ : diameter at breast height regression coefficient,

$D_{\mathrm{ijk}}$ : diameter at breast height for tree $l$, in block $i$, at treatment $j$, of year $k$,

$A_{2}$ : volume index regression coefficient,

$V_{\mathrm{ijk}}$ : volume index for tree $l$, in block $i$, at treatment $j$, of year $k$,

$B_{i}$ : block $i$,

$T_{j}:$ treatment $j$,

$\mathrm{z}_{k}:$ year $k$,

$T z_{j k}:$ year-treatment interaction, and

$e_{i j k l}:$ error.

In this model, the year was considered as a random effect, while the block and treatment were taken as fixed effects. The SAS 9.0 statistical software was used for analysis (SAS Institute Inc., 2002). 


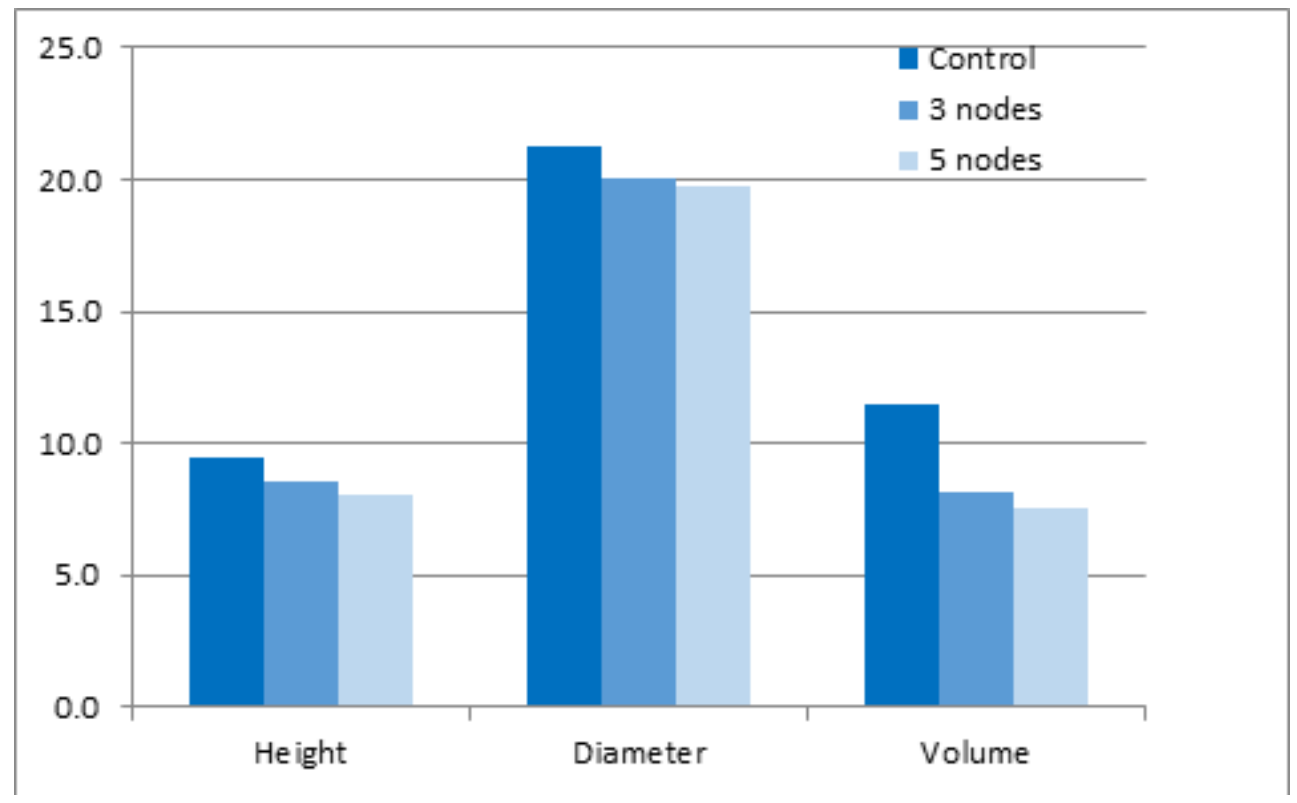

Figure 1. Mean height, diameter at breast height and volume index values for control, three nodes pruning and five nodes pruning at the old seed orchard Slika 1. Srednje vrijednosti visina, prsnog promjera i indeksa volumena za kontrolno orezivanje, orezivanje na tri i pet nodija u staroj sjemenskoj plantaži

\section{RESULTS}

REZULTATI

\section{Growth in ramets - Urod u rametama}

Values for mean heights, diameters at breast height and volume index for the control ramets, the ramets pruned by three nodes, and the ramets pruned by five nodes in the old seed orchard are shown in Figure 1. While the control ramets had the highest values, pruning of 5 nodes lead to the lowest values in all characteristics. Mean height was $9.43 \mathrm{~m}$ for the control, $8.54 \mathrm{~m}$ when three nodes were pruned, and $7.92 \mathrm{~m}$ when five nodes were pruned.

While the mean height of control ramets was $8.90 \mathrm{~m}$ in 2012, it reached to $9.96 \mathrm{~m}$ in 2013 (Figure 2). On the other hand, in ramets with three nodes pruned, the mean heights in 2012 and 2013 were 8.29 and $8.79 \mathrm{~m}$, respectively. While the ramets with five nodes pruned, the mean heights were 7.62 and $8.21 \mathrm{~m}$, respectively, for the same years. In other

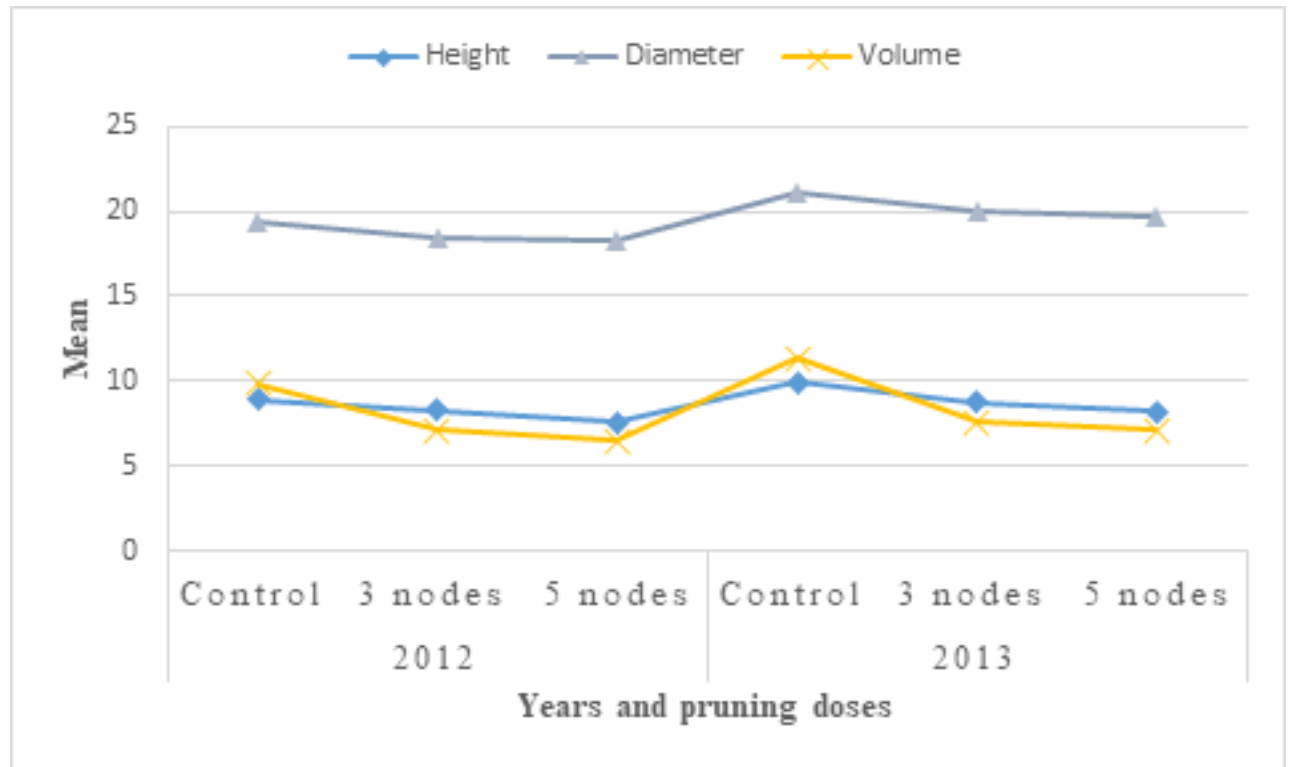

Figure 2. Mean height, diameter at breast height and volume index values for control ramets, ramets pruned by three nodes, and ramets pruned by five nodes from 2012 to 2013 at the old seed orchard

Slika 2. Srednje vrijednosti visina, prsnog promjera i indeksa volumena za kontrolne ramete, ramete orezane na tri nodija i ramete orezane na pet nodija od 2012. do 2013. u staroj sjemenskoj plantaži 


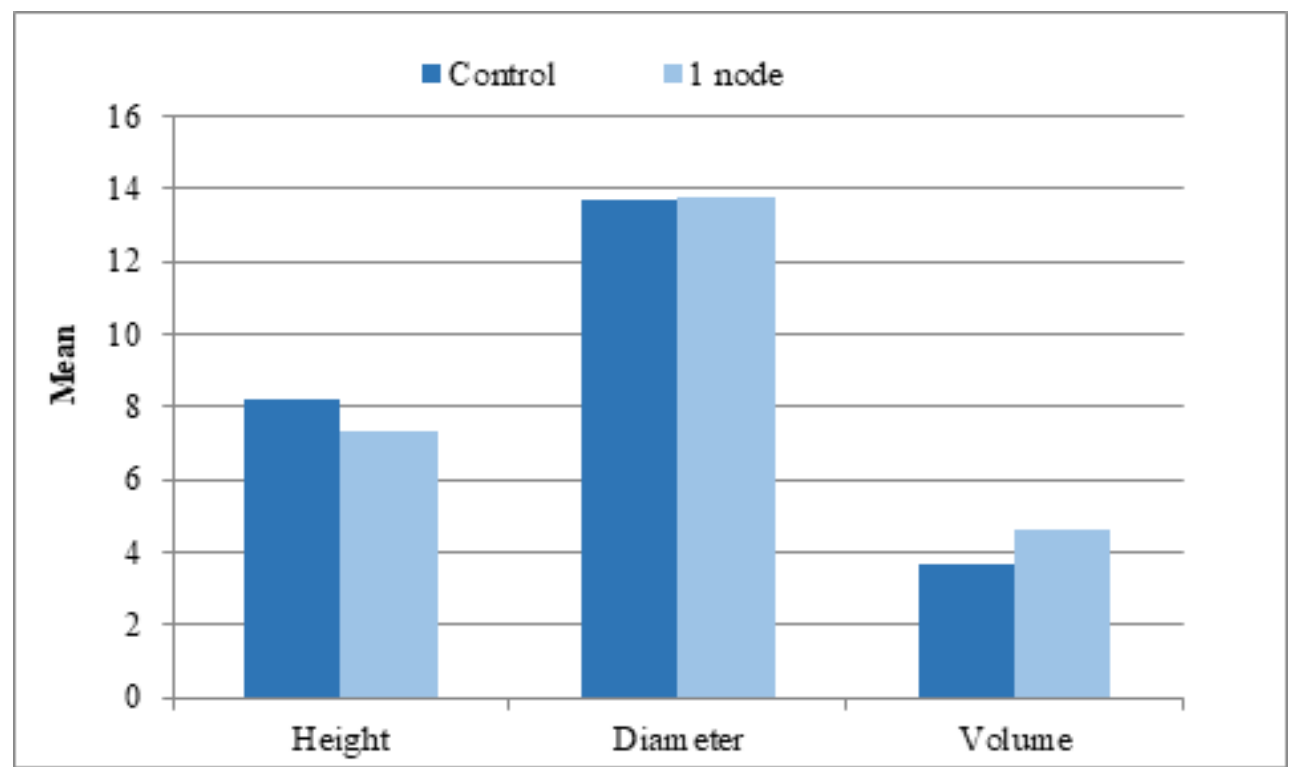

Figure 3. Mean height, diameter at breast height and volume index values for control ramets and ramets pruned at one node at the middle-aged seed orchard

Slika 3. Srednje vrijednosti visina, prsnog promjera i indeksa volumena za kontrolne ramete i ramete orezane na jednom nodiju u sjemenskoj plantaži srednje dobi

words, while the control ramets grew $106 \mathrm{~cm}$ (centimeters) from 2012 to 2013, mean heights increased by $50 \mathrm{~cm}$ when three nodes were pruned, and by $59 \mathrm{~cm}$ when five nodes were pruned during the same period. The difference between the mean heights of control ramets and ramets pruned by three and fivenodes were 60 and $127 \mathrm{~cm}$ in 2012, and 117 and $176 \mathrm{~cm}$, respectively in 2013 .

At the middle-aged seed orchard where trees were pruned by one node, mean heights were $7.33 \mathrm{~m}$ and $8.17 \mathrm{~m}$, diameters at breast height were $13.7 \mathrm{~cm}$ and $13.8 \mathrm{~cm}$, and volume indices were $3.6 \mathrm{dm}^{3}$ and $4.6 \mathrm{dm}^{3}$ for pruning of one node and control ramets respectively (Figure 3 ).

The control ramets reached greater heights than trees pruned by one node by years; similarly, the diameters at breast height were also higher in control ramets in 2012 and 2013, whereas the diameters at breast height were lower in the control ramets than the pruned ramets in the last two years (Figure 4). Furthermore, ramets pruned by one node reached a higher volume index than the control ramets for the entire four years. In 2012, pruning of one node lead to

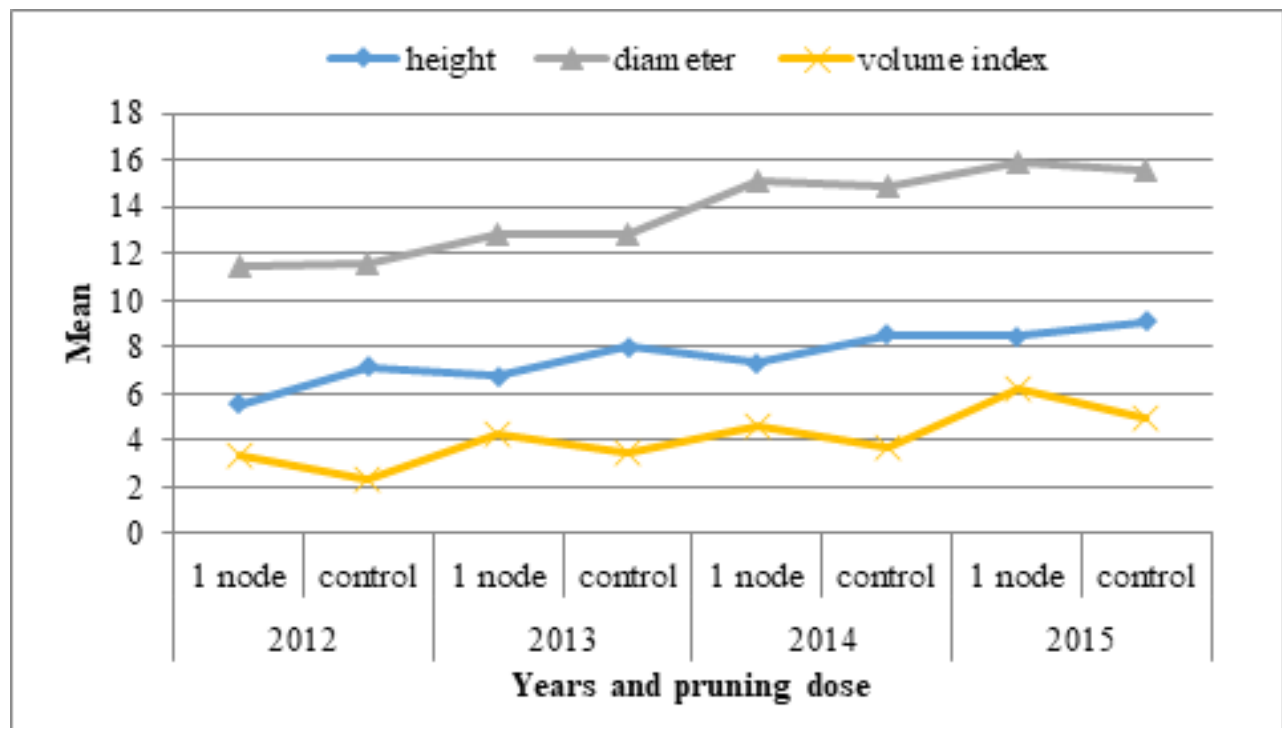

Figure 4.Mean height, diameter at breast heightand volume index values for control ramets and ramets pruned at one node from 2012 to 2015 at the middle aged seed orchard

Slika 4. Srednja vrijednost visina, prsnog promjera i indeksa volumena za kontrolne ramete i ramete orezane na jednom nodiju od 2012. do 2015. u sjemenskoj plantaži srednje dobi 


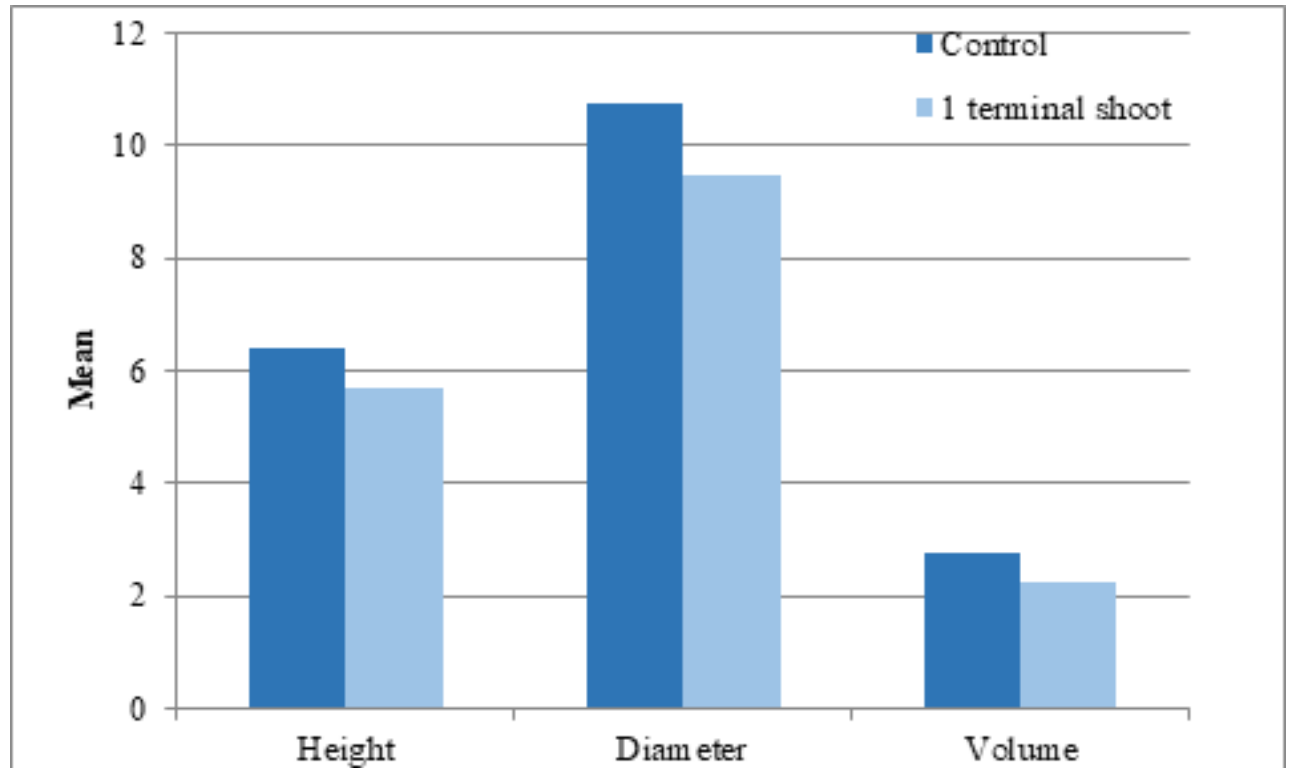

Figure 5. Mean height, diameter at breast height and volume index values for control ramets, and ramets that had their terminal shoots pruned at the young seed orchard

Slika 5. Srednje vrijednosti visine, prsnog promjera i indeksa volumena za kontrolne ramete i ramete s orezanim vršnim izbojcima u mladim sjemenskim plantažama

a decrease in mean height from the $6.79 \mathrm{~m}$ to $5.54 \mathrm{~m} \mathrm{(125}$ $\mathrm{cm})$. While the difference between the mean height of control ramets and the ramets pruned at one node was $159 \mathrm{~cm}$ in 2012, the differences in 2013, 2014 and 2015 were 128, 178 and $58 \mathrm{~cm}$, respectively.

At the young seed orchard where terminal shoots were pruned, control ramets reached a higher average height, di- ameter at breast height and volume index compared to the ramets that had their terminal shoots pruned (Figure 5). The mean height of the control ramets was 6.39 meters, whereas the average height of the ramets with pruned terminal shoots was $5.68 \mathrm{~m}$.

The comparison of the height, diameter at breast height and volume index values according to the years revealed that

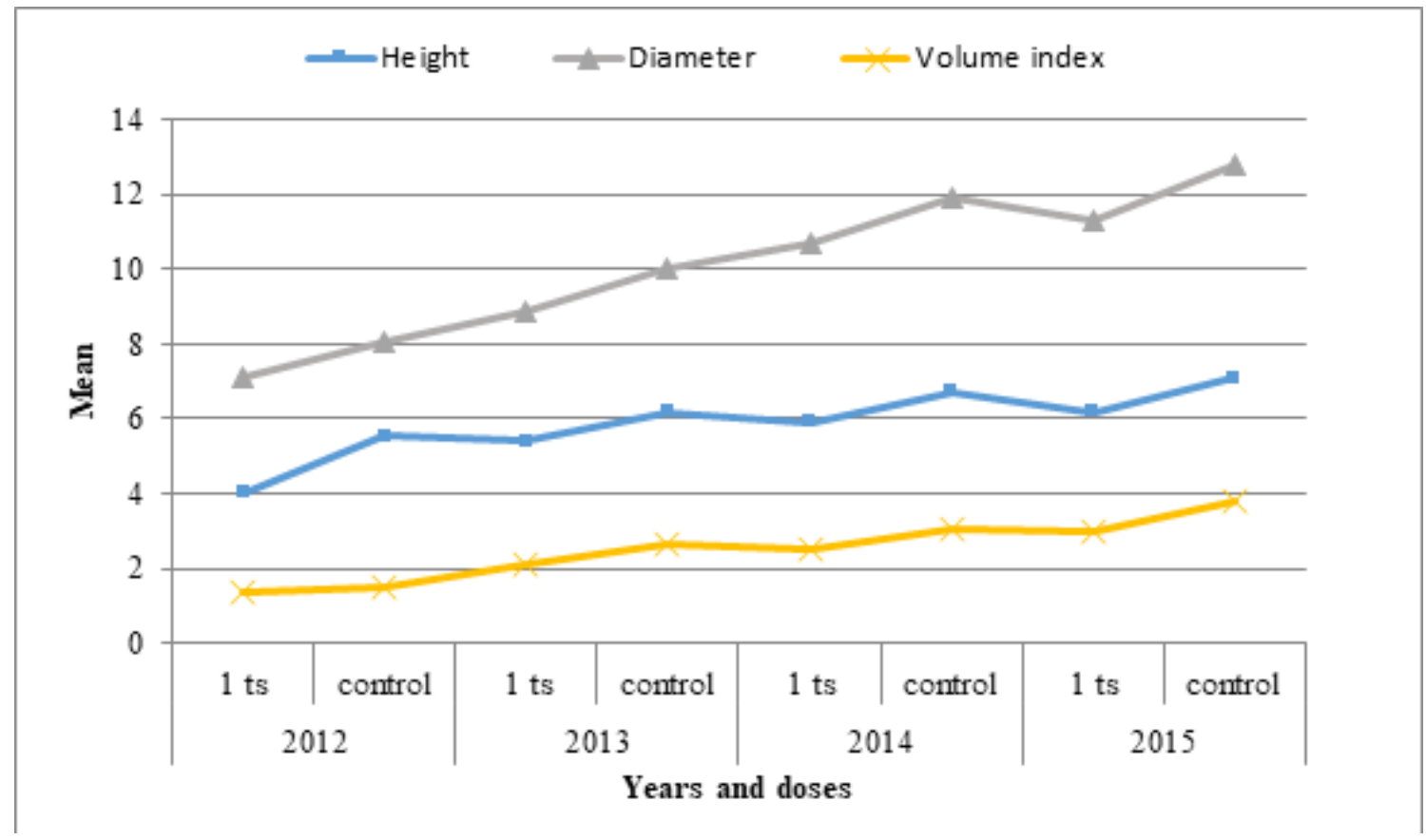

Figure 6. Mean heights, diameters at breast height and volume indices from 2012 to 2015 of the control ramets and the ramets that had their terminal shoots pruned at the young seed orchard

Slika 6. Srednje vrijednosti visine, prsnog promjera i indeksa volumena od 2012. do 2015. za kontrolne ramete i ramete s orezanim vršnim izbojcima u mladim sjemenskim plantažama 
Table 3. Treatment, mean, $( \pm)$ standard error, standard deviation, and minimum and maximum number of conelets and cones at the old seed orchard Tablica 3. Tretiranje, srednja vrijednost, $( \pm)$ standardna greška, standardna devijacija, minimalni i maksimalni broj češerčića i češera u staroj sjemenskoj plantaži

\begin{tabular}{|c|c|c|c|c|c|c|}
\hline $\begin{array}{l}\text { Conolet/cone } \\
\text { Češerčić/ češer }\end{array}$ & $\begin{array}{l}\text { Treatment } \\
\text { Tretiranje }\end{array}$ & $\begin{array}{l}\text { Number grafts } \\
\text { Broj cijepova }\end{array}$ & $\begin{array}{c}\text { Mean } \\
\text { Srednja vrijednost }\end{array}$ & $\begin{array}{l}\text { Standard deviation } \\
\text { Standardna devijacija }\end{array}$ & $\begin{array}{c}\text { Minimum } \\
\text { Minimalni broj }\end{array}$ & $\begin{array}{c}\text { Maximum } \\
\text { Maksimalni broj }\end{array}$ \\
\hline \multirow{3}{*}{$\begin{array}{l}\text { Conelets } \\
\text { Češerčići }\end{array}$} & $\begin{array}{l}\text { Control } \\
\text { Kontrola }\end{array}$ & 90 & $26.21 \pm 1.83$ & 17.36 & 3 & 123 \\
\hline & $\begin{array}{c}3 \text { node } \\
3 \text { nodija }\end{array}$ & 90 & $19.66 \pm 1.85$ & 17.57 & 0 & 123 \\
\hline & $\begin{array}{l}5 \text { node } \\
5 \text { nodija }\end{array}$ & 90 & $18.52 \pm 1.56$ & 14.81 & 0 & 64 \\
\hline \multirow{3}{*}{$\begin{array}{l}\text { Cones } \\
\text { Češeri }\end{array}$} & $\begin{array}{l}\text { Control } \\
\text { Kontrola }\end{array}$ & 90 & $67.50 \pm 5.98$ & 56.82 & 3 & 420 \\
\hline & $\begin{array}{l}3 \text { nodes } \\
3 \text { nodija }\end{array}$ & 90 & $70.40 \pm 8.46$ & 80.34 & 3 & 452 \\
\hline & $\begin{array}{l}5 \text { nodes } \\
5 \text { nodija }\end{array}$ & 90 & $58.33 \pm 5.52$ & 52.38 & 0 & 238 \\
\hline
\end{tabular}

the mean values of the control ramets were higher than pruned clones (Figure 6). In 2012, the mean height was decreased from $5.20 \mathrm{~m}$ to $4.02 \mathrm{~m}(118 \mathrm{~cm})$ through the pruning of terminal shoots. While the difference between the mean heights of the control ramets and of ramets with pruned terminal shoots was $153 \mathrm{~cm}$ in 2012, the differences in 2013, 2014 and 2015 were $78 \mathrm{~cm}, 80 \mathrm{~cm}$ and $92 \mathrm{~cm}$, respectively. At the end of four years, the diameters of control ramets grew $1.5 \mathrm{~cm}$ larger than the diameter of ramets that had their terminal shoots pruned.

\section{Conelet and cone production - Urod češerčića $i$ češera}

At the old seed orchard, mean number of conelets of the control ramets was 26.21 , while the mean number of conelets of the ramets pruned by three and five nodes were 19.66 and 18.52, respectively. The average number of cones at the old seed orchard, in turn, were $67.50,70.40$ and 58.33, respectively (Table 3 ).
In 2012, mean number of cones was very high when compared to other years (Figure 7). Even though the control ramets had a higher average, the average number of cones was higher in 2012 for ramets pruned at 3 nodes. The control ramets reached a higher number of conelets than the ramets that were pruned.

The analysis of variance for the old seed orchard revealed that thenumber of cones was statistically significant for the years (Table 4). Even though the block was statistically significant in terms of the number of conelets, the other factors were found to be statistically non-significant for the numbers of conelets and cones. In addition, diameter at breast height and volume index, which were included into the model as covariates, didn't effect on conelet and cone production.

At the middle-aged seed orchard for the control ramets and ramets pruned at one node, the three-year mean conelet number was 11.34 and 9.56, respectively, while mean cone number was 13.18 and 9.23, respectively (Table 5).

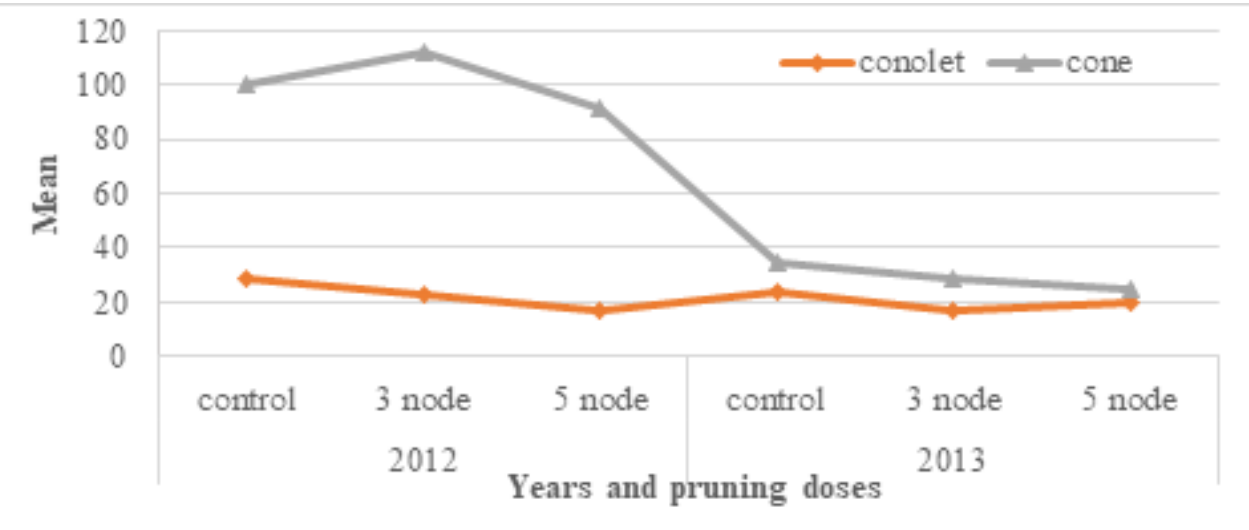

Figure 7. Mean number of conelets and cones from 2012 to 2015 for the control ramets and the ramets pruned by three and five nodes at old seed orchard

Slika 7. Prosječni broj češerčića i češera od 2012. do 2015. za kontrolne ramete i ramete orezane na tri i pet nodija u staroj sjemenskoj plantaži 
Table 4. Analysis of variance in relation to conelet and cone production for old seed orchard

Tablica 4. Analiza varijance vezano za urod češerčića i češera u staroj sjemenskoj plantaži

\begin{tabular}{|c|c|c|c|}
\hline $\begin{array}{l}\text { Source of } \\
\text { variation }\end{array}$ & $\begin{array}{l}\text { Degree of } \\
\text { freedom }\end{array}$ & $\begin{array}{l}\text { Mean square } \\
\text { of conolets }\end{array}$ & $\begin{array}{l}\text { Mean square } \\
\text { of cones }\end{array}$ \\
\hline $\begin{array}{c}\text { Izvor } \\
\text { varijabilnosti }\end{array}$ & $\begin{array}{l}\text { Stupanj } \\
\text { slobode }\end{array}$ & $\begin{array}{l}\text { Srednji kvadrat } \\
\text { za češerčiće }\end{array}$ & $\begin{array}{c}\text { Srednji kvadrat } \\
\text { za češere }\end{array}$ \\
\hline $\begin{array}{c}\text { Diameter }(\mathrm{cm}) \\
\text { Promjer }\end{array}$ & 1 & $0.118 \mathrm{~ns}$ & $0.161 \mathrm{~ns}$ \\
\hline $\begin{array}{l}\text { Volume index }\left(\mathrm{dm}^{3}\right) \\
\text { Indeks volumena }\end{array}$ & 1 & $0.002 \mathrm{~ns}$ & $0.001 \mathrm{~ns}$ \\
\hline $\begin{array}{l}\text { Block } \\
\text { Blok }\end{array}$ & 4 & $0.378^{*}$ & $0.131 \mathrm{~ns}$ \\
\hline $\begin{array}{l}\text { Treatment } \\
\text { Tretiranje }\end{array}$ & 2 & $0.021 \mathrm{~ns}$ & $0.101 \mathrm{~ns}$ \\
\hline $\begin{array}{l}\text { Year } \\
\text { Godina }\end{array}$ & 1 & $0.315 \mathrm{~ns}$ & $8.353^{* *}$ \\
\hline $\begin{array}{c}\text { Year*treatment } \\
\text { Godina*tretiranje }\end{array}$ & 2 & $0.105 n s$ & $0.179 \mathrm{~ns}$ \\
\hline $\begin{array}{l}\text { Error } \\
\text { Greška }\end{array}$ & 18 & 0.081 & 0.138 \\
\hline
\end{tabular}

ns: non-significant, ${ }^{*}$ significant at $0.01,{ }^{* *}$ significant at 0.001 ns: nije značajno, ${ }^{*}$ značajno pri 0,01, **značajno pri 0,001
Except for the average number of conelets in 2015, control ramets in the middle-aged seed orchard reached higher conelet and cone averages than the pruned ramets. Even though the average number of cones was relatively low both for control and pruned ramets in 2013, it was increased in 2014 and 2015 for both groups (Figure 8).

In the analysis of variance conducted for the middle-aged seed orchard, none of the factors were found to be significant(Table 6). Neither the diameter at breast height, nor the volume index was found to have a statistically significant effect on the number of conelets and cones.

Three-year data on conelets and cones for the young seed orchard are given in Table 7. While mean conelet number was 22.52 for control ramets and 20.96 for the pruned ramets. Mean cone numbers for the control ramets and pruned ramets were 17.83 and 16.89 , respectively.

Although pruned ramets had a higher mean conelet number in 2014 and a higher mean cone number in 2015 than the control ramets in the young seed orchard, both numbers were lower in the other years (Figure 9). Since cone

Table 5. Treatment, mean, $( \pm)$ standard error, standard deviation, minimum and maximum number of conelets and cones for middle aged seed orchard

Tablica 5. Tretiranje, srednja vrijednost, ( \pm ) standardna greška, standardna devijacija, minimalni i maksimalni broj češerčića i češera u sjemenskoj plantaži srednje dobi

\begin{tabular}{|c|c|c|c|c|c|c|}
\hline $\begin{array}{l}\text { Conolet/cone } \\
\text { Češerčići/češeri }\end{array}$ & $\begin{array}{l}\text { Treatment } \\
\text { Tretiranje }\end{array}$ & $\begin{array}{l}\text { Graft numbers } \\
\text { Broj cijepova }\end{array}$ & $\begin{array}{c}\text { Mean } \\
\text { Srednja vrijednost }\end{array}$ & $\begin{array}{l}\text { Standard deviation } \\
\text { Standardna devijacija }\end{array}$ & $\begin{array}{c}\text { Minimum } \\
\text { Minimalni broj }\end{array}$ & $\begin{array}{c}\text { Maximum } \\
\text { Maksimalni broj }\end{array}$ \\
\hline \multirow{2}{*}{$\begin{array}{l}\text { Conolets } \\
\text { Češerčići }\end{array}$} & $\begin{array}{l}\text { Control } \\
\text { Kontrola }\end{array}$ & 117 & $11.34 \pm 1.16$ & 12.51 & 0 & 73 \\
\hline & $\begin{array}{l}1 \text { node } \\
1 \text { nodij }\end{array}$ & 126 & $9.56 \pm 0.82$ & 9.31 & 0 & 51 \\
\hline \multirow{2}{*}{$\begin{array}{l}\text { Cones } \\
\text { Češeri }\end{array}$} & $\begin{array}{l}\text { Control } \\
\text { Kontrola }\end{array}$ & 117 & $13.18 \pm 1.74$ & 18.85 & 0 & 93 \\
\hline & $\begin{array}{l}1 \text { node } \\
1 \text { nodij }\end{array}$ & 126 & $9.23 \pm 1.24$ & 13.93 & 0 & 83 \\
\hline
\end{tabular}

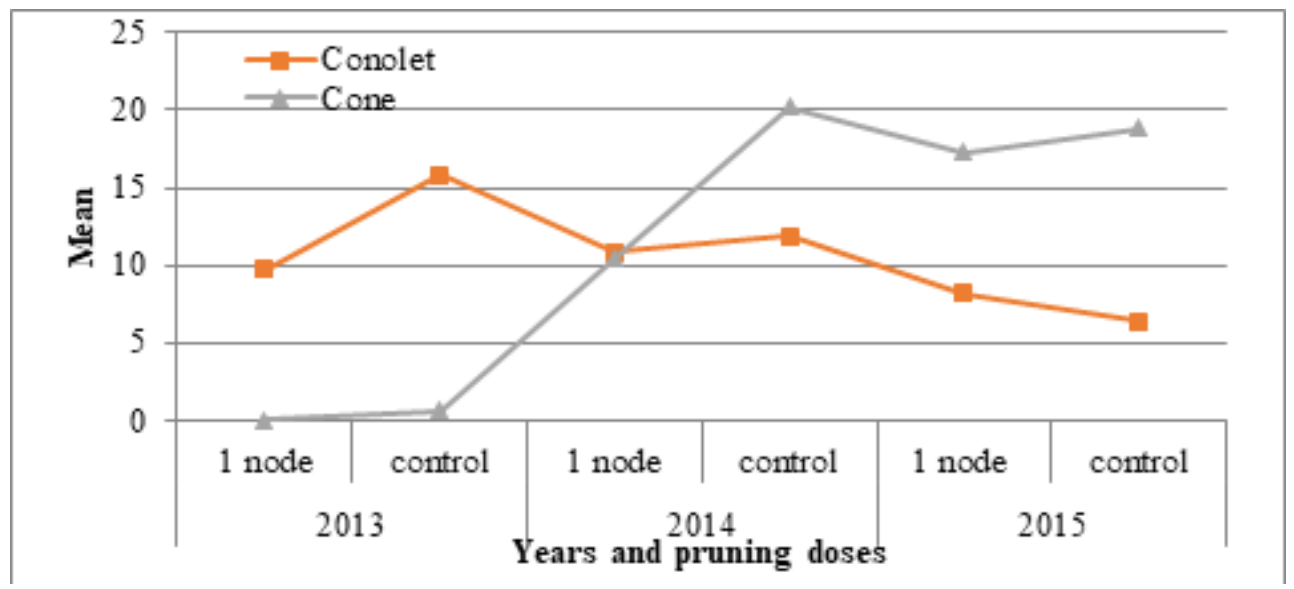

Figure 8. Mean number of conelets and cones for control ramets and ramets pruned by one node from 2013 to 2015 at the middle aged seed orchard Slika 8. Srednji broj češerčića i češera za kontrolne ramete i ramete orezane na jednom nodiju od 2013. do 2015.u sjemenskim plantažama srednje dobi 
Table 6. Analysis of variance regarding number of conelets and cones at the middle aged seed orchard

Tablica 6. Analiza varijance vezano za broj češerčića i češera u sjemenskim plantažama srednje dobi

\begin{tabular}{|c|ccc|}
\hline $\begin{array}{c}\text { Source of varaition } \\
\text { Izvor varijabilnosti }\end{array}$ & $\begin{array}{c}\text { Degree of } \\
\text { freedom } \\
\text { Stupanj } \\
\text { slobode }\end{array}$ & $\begin{array}{c}\text { Mean square } \\
\text { of conolet } \\
\text { Srednji } \\
\text { kvadrat za } \\
\text { češerčiće }\end{array}$ & $\begin{array}{c}\text { Mean square } \\
\text { of cone } \\
\text { Srednji } \\
\text { kvadrat za } \\
\text { češere }\end{array}$ \\
$\begin{array}{c}\text { Diameter }(\mathrm{cm}) \\
\text { Promjer }\end{array}$ & 1 & $0.158 \mathrm{~ns}$ & $0.026 \mathrm{~ns}$ \\
\hline $\begin{array}{c}\text { Volume index }\left(\mathrm{dm}^{3}\right) \\
\text { Indeks volumena } \\
\text { Block } \\
\text { Blok }\end{array}$ & 1 & $0.345 \mathrm{~ns}$ & $0.008 \mathrm{~ns}$ \\
\hline $\begin{array}{c}\text { Treatment } \\
\text { Tretiranje } \\
\text { Year } \\
\text { Godina }\end{array}$ & 1 & $0.064 \mathrm{~ns}$ & $0.081 \mathrm{~ns}$ \\
\hline $\begin{array}{c}\text { Year*treatment } \\
\text { Godina*tretiranje }\end{array}$ & 2 & $0.435 \mathrm{~ns}$ & $1.033 \mathrm{~ns}$ \\
\hline $\begin{array}{c}\text { Error } \\
\text { Greška }\end{array}$ & 18 & $0.442 \mathrm{~ns}$ & $1.475 \mathrm{~ns}$ \\
\hline
\end{tabular}

ns: non-significant

ns: nije značajno
Table 8. Analysis of variance regarding number of conelets and cones at the young seed orchard

Tablica 8. Analiza varijance vezano za broj češerčića i češera u mladoj sjemenskoj plantaži

\begin{tabular}{|c|c|c|c|}
\hline $\begin{array}{l}\text { Source of variation } \\
\text { Izvor varijabilnosti }\end{array}$ & $\begin{array}{l}\text { Degree of } \\
\text { freedom } \\
\text { Stupanj } \\
\text { slobode }\end{array}$ & $\begin{array}{l}\text { Mean square } \\
\text { of conelet } \\
\text { Srednji } \\
\text { kvadrat za } \\
\text { mlade češere }\end{array}$ & $\begin{array}{l}\text { Mean square } \\
\text { of cone } \\
\text { Srednji } \\
\text { kvadrat za } \\
\text { zrele češere }\end{array}$ \\
\hline $\begin{array}{c}\text { Diameter }(\mathrm{cm}) \\
\text { Promjer }\end{array}$ & 1 & $0.029 \mathrm{~ns}$ & $0.057 \mathrm{~ns}$ \\
\hline $\begin{array}{l}\text { Volume index }\left(\mathrm{dm}^{3}\right) \\
\text { Indeks volumena }\end{array}$ & 1 & $0.758^{* *}$ & $0.445 \mathrm{~ns}$ \\
\hline $\begin{array}{l}\text { Block } \\
\text { Blok }\end{array}$ & 4 & $0.388^{* *}$ & $0.219 \mathrm{~ns}$ \\
\hline $\begin{array}{l}\text { Treatment } \\
\text { Tretiranje }\end{array}$ & 1 & $0.079 \mathrm{~ns}$ & $0.145 \mathrm{~ns}$ \\
\hline $\begin{array}{l}\text { Year } \\
\text { Godina }\end{array}$ & 2 & $1.357 \mathrm{~ns}$ & $1.475 \mathrm{~ns}$ \\
\hline $\begin{array}{l}\text { Year*treatment } \\
\text { Godina*tretiranje }\end{array}$ & 2 & $1.672^{* *}$ & $3.236^{* *}$ \\
\hline $\begin{array}{l}\text { Error } \\
\text { Greška }\end{array}$ & 18 & 0.151 & 0.092 \\
\hline
\end{tabular}

ns: non-significant, ${ }^{* *}$ significant at 0.001

ns: nije značajno, ${ }^{* *}$ značajno pri 0,001

Table 7. Treatment, mean, standard error $( \pm)$, standard deviation, minimum and maximum number of conelets and cones for the young seed orchard Tablica 7. Tretiranje, srednja vrijednost, ( \pm ) standardna greška, standardna devijacija, minimalni i maksimalni broj češerčića i češera u mladoj sjemenskoj plantaži

$\begin{array}{ccccccc}\begin{array}{c}\text { Conolet/cone } \\ \text { Češerčići/češeri }\end{array} & \begin{array}{c}\text { Treatment } \\ \text { Tretiranje }\end{array} & \begin{array}{c}\text { Number of grafts } \\ \text { Broj cijepova }\end{array} & \begin{array}{c}\text { Mean } \\ \text { Srednja vrijednost }\end{array} & \begin{array}{c}\text { Standard deviation } \\ \text { Standardna devijacija }\end{array} & \begin{array}{c}\text { Minimum } \\ \text { Minimalni broj }\end{array} & \begin{array}{c}\text { Maximum } \\ \text { Maksimalni broj }\end{array} \\ \begin{array}{c}\text { Control } \\ \text { Conolets }\end{array} & \begin{array}{c}\text { Kontrola } \\ \text { Termiňici }\end{array} & 123 & 22.52 \pm 1.68 & 18.68 & 2 & 88 \\ & \begin{array}{c}\text { Vršni izbojak } \\ \text { Control }\end{array} & 115 & 20.96 \pm 1.85 & 19.92 & 2 & 116 \\ \begin{array}{c}\text { Kontrola } \\ \text { Cones }\end{array} & 123 & 17.83 \pm 2.59 & 27.82 & 0 & 103 \\ \text { Češeri } & \begin{array}{c}\text { Terminal shoot } \\ \text { Vršni izbojak }\end{array} & 115 & 16.89 \pm 1.84 & 20.42 & 0 & 156\end{array}$

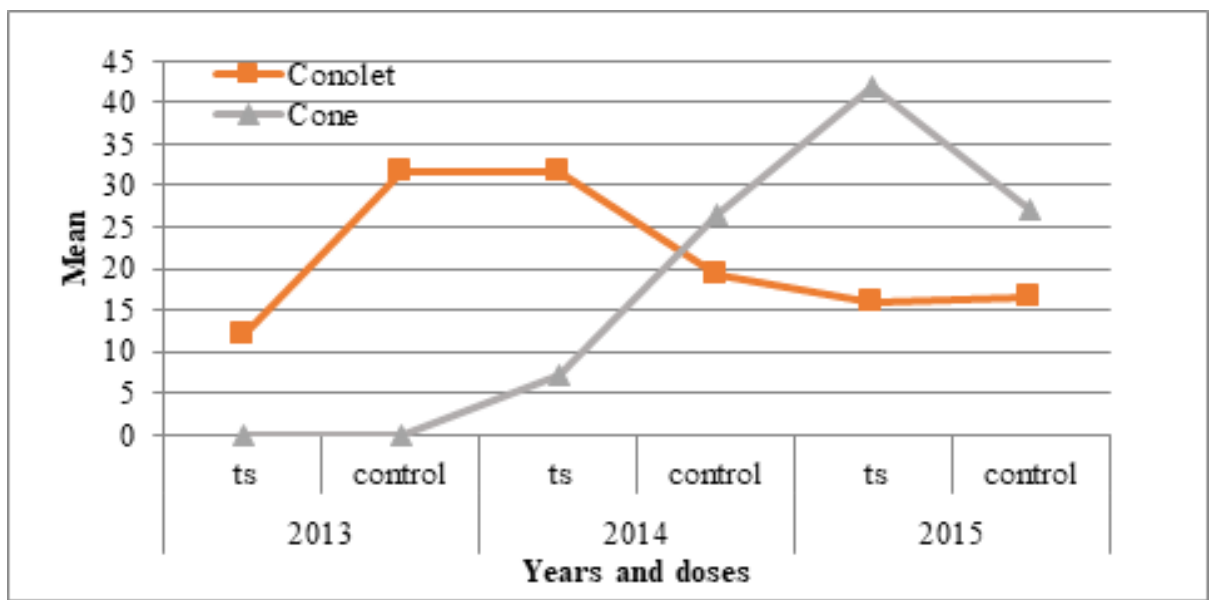

Figure 9. Average number of conelets and cones for the control ramets and the ramets with pruned terminal shoots (ts) from 2013 to 2015 at the young seed orchard

Slika 9. Prosječan broj češerčića i češera za kontrolne ramete i ramete s orezanim vršnim izbojcima (ts) od 2013. do 2015. u mladoj sjemenskoj plantaži 
production was very low in 2013 in the control ramets and the ramets with pruned terminal shoots, the cones were not counted.

The analysis of variance conducted for the young seed orchard revealed that year-treatment interaction was significant both for conelet and cone production, and while the volume index and block were statistically significant for conelet production, the rest of the factors were non-significant (Table 8). No statistically significant difference was found for conelet or cone production with respect to treatment (control ramets, pruning of terminal shoots). It was found that volume index had an impact on conelet production, whereas diameter and volume index had no impact on cone production.

\section{DISCUSSION}

\section{RASPRAVA}

In the old seed orchard, mean height, diameter at breast height and volume index declined in ramets pruned by three and five nodes. The decline was larger in ramets pruned by five nodes. The decrease in volume index occurred in parallel with the shortening in height. Therefore, it was assumed that the decline in volume index may be due to the shortening of height, since the crown diameters remained more or less the same. On the other hand, in ramets pruned by three nodes and five nodes, diameter at breast height was found to be $1.0 \mathrm{~cm}$ and $1.6 \mathrm{~cm}$ lower, respectively, compared to the control ramets. The reduction in diameter at breast height was in parallel with the degree of pruning. The reduction in diameter at breast height was considered to be a result of the reduction in the top surface, hence in the rate of photosynthesis.

After two years, the average height of the control rametswas $117 \mathrm{~cm}$ and $176 \mathrm{~cm}$ tallerthan the ramets pruned by three and five nodes respectively. In 2008, heights in ramets pruned by three and five nodes were reduced by $25 \%$ ( 184 $\mathrm{cm})$ and $39 \%(302 \mathrm{~cm})$, respectively, while the control ramets were $202 \mathrm{~cm}$ and $283 \mathrm{~cm}$ taller than ramets pruned by three and five nodes. In the six years,since the first pruning, it was found that the difference between the heights of the control ramets and ramets pruned by three nodes and five nodes declined to $85 \mathrm{~cm}$ and $107 \mathrm{~cm}$, respectively. In other words, the growth in the height of the pruned ramets was proportionally higher than the growth in the control ramets.

In the old seed orchard, cone production was higher in 2012 than 2013. Since cone production was high both in the control and pruned ramets, it was assumed that 2012 was a year of high seed yield. On the other hand, ramets pruned by three nodes reached a higher average number of cone production than control ramets in 2012. However, when 2012 and 2013 are considered together, there was no explicit trend in terms of cone production either in the control ramets or in the pruned ramets. In fact, only the year factor was found to be statistically significant in the analysis of variance, which was likely due to 2012 being a year of high yield, as previously mentioned. No difference was also found between treatments in the old Turkish red pine seed orchard in the preliminary study covering the period 20092011 (Alan et al. 2011). Similarly, in a 14-year-old lodgepole pine (Pinus contorta Douglas.) seed orchard, no significant difference was found in terms of cone production with respect to height (Stoehr et al. 1995). But, in a 20-year-old Turkish red pine clone park, $15 \%$ pruning was found to increase the number of female flowers and cones compared with the control clones (Sengun and Semerci 2002). Likewise, in a 17-year-old white spruce (Picea glauca (Moench) Voss.) seed orchard where two to five nodes were pruned, it was determined following a four-year period after pruning that the pruning of three and four nodes resulted in an increase in cone production (Nienstaedt 1981). In the study of Turkish red pine by Sengun and Semerci (2002), only one year's cone crops were counted, a more moderate top pruning was used, aflat topping method was applied instead, and the evaluation was carried out at the clonal level. So, the difference observed in the study of Turkish red pine (Sengun and Semerci 2002) might be due to one or more of these factors. On the other hand, the increase in cone production in white spruce with pruning (Nienstaedt 1981) might be due the difference in species.

In the middle-aged seed orchard, the heights of ramets were shortened by $18 \%$ through pruning. While the difference between mean height of control and pruned ramets was 159 $\mathrm{cm}$ in 2012, it was $58 \mathrm{~cm}$ in 2015. Although the control ramets remained taller for the entire four-year period, it was seen that pruned ramets grew proportionally faster.

The second pruning age (12 years) of the middle-aged seed orchard was close to the first pruning age (15 years) of the old seed orchard. In the middle aged Turkish red pine seed orchard, the spacing used $(5 \times 5)$ was narrower than the one generally used $(7 \times 7,8 \times 8,9 \times 9)$, and thinning was planned in the future. Since the volumes of control ramets decreased, it was assumed that the crown diameters of pruned ramets grew larger. In a similar study, Copes and Bordelon (1994) identified more extensive growth at the crowns of pruned trees in two Douglas-fir (Pseudotsuga menziesii (Mirb.) Franco var. menziesii) seed orchards aged 17 and 22 years. On the other hand, in a western hemlock (Tsuga heterophylla (Raf.) Sarg.) seed orchard, it was found that severe (50\%) and moderate (25\%) pruning eliminated or considerably delayed the need for thinning (Ross 1989). It was determined that pruning also substitutedfor a certain extent the need for thinning in the middle-aged seed orchard, based on the crown development and the increase in vol- 
ume index observed in the pruned ramets. It was assumed that ramets surpressed the middle-aged seed orchard developed different physiological strategies as a result of different morphological structures.

Although the diameters at breast height of control ramets in the middle-aged seed orchard were larger than the pruned ramets in the first two years (2012 and 2013), it dropped behind in the following two years (2014 and 2015). While these changes were taking place in the diameters at breast height, control ramets continued to remain taller than the pruned ramets throughout these four years. This was assumed to be a result of the faster growth in the crowns of the pruned ramets. It was also assumed that the increase in the size of crowns led to an increase in the volume index, which in turn lead to an increase in the area of photosynthesis that resulted in higher diameters. Accordingly, the volume indices of pruned ramets have always been higher than that of control ramets in each year between 2012 and 2015. It was thought that the need of thinning arose in the previous years, and that the pruning of ramets at one node in 2008 lead to the development of their crowns. This, in turn, led the pruned ramets to have a larger volume index during the entire four-year period. Moreover, as the ramets were pruned by a node in 2008, their height decreased 134 $\mathrm{cm}(26 \%)$ on average, and the difference between the heights of control and pruned ramets were $71 \mathrm{~cm}$ (Alan et al. 2011).

There was no statistically significant difference between control ramets and ramets pruned by one node in terms of their three-year conelet and cone production. In other words, the ramets that were pruned and shortened heights (average $125 \mathrm{~cm}$ ) produced the same amount of conelets and cones with control ramets; however, the quantity of conelets and cones in the middle-aged seed orchard was lower than that in the young seed orchard. This finding was assumed to be due to the fact that the ramets in the middleaged seed orchard were packed very densely, which indicated that, even though they had developed their crown diameters as a result of pruning, they still required thinning. In the young seed orchard, the four-year averages of height, diameter at breast height and volume index was larger in the control ramets than in the ramets whose terminal shoots were pruned. Nevertheless, the difference between the heights of control ramets and of the ramets whose terminal shoots were pruned dropped from $153 \mathrm{~cm}$ in 2012 to $92 \mathrm{~cm}$ in 2015, indicating that pruned ramets had grown proportionally faster than the unpruned ramets. Similarly, Greenwood and Bramlett (1989) observed that when ramets over two and three meters height were top pruned in a young loblolly pine seed orchard, their average heights decreased by 12 to $33 \%$, while their average diameter at breast height decreased by 6 to $18 \%$. In light of this information, it was understood that pruning in young seed orchards not only led to a decline in height, but also to a reduction in diameter at breast height.

The young seed orchard had not yet reached maturity (eight years), which is required for conelet and cone production. However, it still produced more conelets and cones than the middle-aged seed orchard. In both seed orchards, $5 \times 5 \mathrm{~m}$ of spacing was used; however, even though the stand density in the middle-aged seed orchards was high, the same situation was not observed in the young seed orchard. It was understood that the high stand density in the middle-aged seed orchard lead to an overall reduction in the amount of light received, which in turn prevented crown development.

In the young seed orchard, no difference was observed between the untreated controls and pruned ramets in terms of conelet and cone production. Matheson and Willcocks (1976) concluded that the yield and age of production of Pinus radiata seed orchards increased with top pruning. Similarly, Nienstaedt (1981) also suggested that top pruning increases seed yield, and thus reduces costs, and that reduced tree height has made seed collection easier and safer. While Gerwig (1987) concluded that top pruning enables the control of tree height, he also pointed out that the effect of pruning on cone production varies according to tree species, age and the degree of pruning. On the other hand, studies have also emphasized the importance of beginning to shape the tree crown by pruning at a young age, and of increasing the flowering parts by creating a denser crown (Stoehr et al. 1995; Smith 2004). Kolpak et al. (2015) reported that, as an alternative to conventional seed orchards, they developed miniaturized seed orchards with Douglas-fir. In these seed orchards (five to seven years old) modeled on fruit orchards, researchers topped the ramets every two years, suggesting that the removal of flower buds affected the physiologies of the clones; however, they did not identify a significant difference between pruned and unpruned clones in terms of productivity (female flower, male flower). On the other hand, Stoehr et al. (1995) showed that cone production dropped considerably in severely topped (50\%) clone with respect to the untreated clones in a young lodgepole pine seed orchard, revealing that severe pruning did not yield in favorable results in young seed orchards. Then again, Gerwig (1987) indicated that pruning of trees every year for five years in a young and yet unproductive loblolly pineseed orchard shortened height by 300 $\mathrm{cm}$ with respect to unpruned controls, and led to an acceptable reduction in average yield; however, he also highlighted that pruning done in mid-summer instead of spring led to relatively better results. In a study in which leading shoots were pruned at different regimes for six years in a Douglasfir seed orchard, Copes (1973) decided to repeat the pruning process at the end of each year. Similarly, in a study conducted with western larch, results suggested that the best 
shoot pruning regimes for western larch (Larix occidentalis Nutt.) crown management were removal of 50-75\% of the current shoot, while maintaining top height to $4-5 \mathrm{~m}$ (Webber et al. 2003). In the same study, to prune to $3 \mathrm{~m}$ once a height of $5 \mathrm{~m}$ was not suggested. In light of these findings, it was considered that the terminal shoot pruning performed in the young Turkish red pine seed orchards is compatible/similar to the approach of "slightly top pruning at frequent intervals" that is generally applied in young seed orchards. Nevertheless, it was assumed that pruning at different periods of the year instead of pruning only during spring might be a more viable choice for Turkish red pine seed orchards.

With regard to seed orchard management, no significant difference was found in terms of conelet and cone production between the untreated controls and the pruned ramets in the seed orchards that were employed in the study. Conversely, there were differences between the morphologies, and hence physiologies, of individual trees in each of the three seed orchards. In the middle-aged and young seed orchards, the heights of the pruned ramets were reduced by $18 \%$ and $21 \%$, respectively, in 2012 . While the difference between control and pruned ramets in the middle-aged seed orchard remained stable from 2012 to 2014, it declined in 2015. The difference between the heights of control and pruned ramets in the young seed orchard disappeared almost entirely in 2013, and continued as such until 2015. At the end of the six-year period in the old seed orchard, the difference between the untreated controls and the ramets pruned by three nodes dropped from $202 \mathrm{~cm}$ to $117 \mathrm{~cm}$, while the difference between the untreated controls and the ramets pruned by five nodes dropped from $302 \mathrm{~cm}$ to 176 $\mathrm{cm}$. Therefore, in all seed orchards, the common outcome of top pruning was that it enabled a reduction of tree height. Miller and DeBell (2013) indicated that top pruning is used in many species, and helps eliminate the need to use man lifts. On the other hand, the observations made over five years on Aleppo pines, which can be crossbred with Turkish red pine naturally, revealed that there was no correlation between height and the female flower and cone production (Matziris 1997). Another study demonstrated that there were no biological constraints that required seed orchard managers to plan for target heights by pruning (Almqwist and Jansson 2015). Based on these findings, to prune the terminal shoots every year in young seed orchards; to prune three nodes in middle-aged seed orchards every three years; and to prune three nodes in old seed orchards in every four years can be applied. For old seed orchards, it was found that a one-time five node pruning may be sufficient, or that the procedure could be repeated at the end of four years. In sum, top pruning can be used at different levels and different periods as a management tool in young, middle-aged and old seed orchards.

\section{CONCLUSION} ZAKLJUČAK

Top pruning in seed orchards of different ages ensured that heights remained shorter compared to untreated controls by the end of the four-year period. In addition to the reduction in height, a reduction in diameter at breast height and volume index was also observed. Nonetheless, in the middle-aged seed orchard that required further thinning, it was observed that, despite the reduction in height, the volume indices of pruned ramets increased, in contrast to those in the other seed orchards.

In Turkish red pine seed orchards of different ages, mean heights were reduced by $18 \%$ to $39 \%$, and the terminal shoot and node numbers were used instead of proportional measurements (due to their ease of application), and no difference between pruned and unprunedrametswas observed in terms of conelet and cone production.

It was concluded that pruning by three nodes could be repeated every four years, or that ramets could be pruned by five nodes in a single application, or pruning five node could be repeated once again every four yearsin the old seed orchard. One-node pruning can be repeated in every three years in the middle-aged seed orchard, and that terminal shoot pruning can be repeated every year in the young seed orchard.

It was seen that in seed orchards where thinning cannot be applied immediately, top pruning can be applicated as an alternative.

The study revealed that top pruning can be used as a seed orchard management tool at different levels and periods, in accordance with the age of seed orchards.

\section{ACKNOWLEDGEMENT ZAHVALA}

The study was generated from a research project (Project number: ANK-029 1620/2008-2019) of Forest Tree Seeds and Tree Breeding Research Directorate (FTSTBRD). Support and assistance of FTSTBRD is gratefully acknowledged. This work was also supported by Scientific Research Projects Coordination Unit of Karabük University. Project Number: (KBU-BAP-16/2-BM-034).

\section{REFERENCES}

\section{LITERATURA}

- Alan, M., 2012: Breeding of Turkish red pine of in Turkey: past, present and future. Kuruluşunun 60. Yllında Ormancilık Araştırma Enstitüleri: Dünü, Bugünü ve Geleceği Sempozyumu, 7-9 Kasım, Bolu:212-220 (in Turkish with English abstract).

- Alan, M., H. Ozler, R. Sabuncu, T. Ezen, B. Calışkan, N. Ozbedel, 2011: Effects of pruning on strobili of different age Turkish 
red pine (Pinus brutiaTen.) seed orchards: results of first three years. Orman Ağaçları ve Tohumları Islah Araştırma Enstitüsü Müdürlüğü Teknik Bülten Serisi No: 28. (in Turkish with English abstract).

- Almqvist, C., G. Jansson, 2015: Effects of pruning and stand density on cone and pollen production in an experimental Pinus sylvestris seed orchard. Silva Fennica, 49 (4): 1-16.

- Bilgen, B. B., M. Alan, Y. Kurt, 2013: Importance of effective clone number in seed orchards: a comparative study on seven conifer species in Turkey. Sumarski List, 5-6: 297-306.

- Bramlett, D.L., 1991: Seed orchard management:successes, problems and challenges. In: Proc. 21th Southern For. Tree Imp. Conf. : 82-92.

- Codesido, V., J. Fernandez-Lopez, 2014: Juvenile radiata pine clonal seed orchard management in Galicia (NW Spain). Eur J Forest Res, 133:177-190.

- Copes, D.L., 1973: Effect of annual leader pruning on cone production and crown development of grafted douglas-fir. Silvae Genetica, 22: 167-173

- Copes, D.L., M. Bordelon, 1994: Effects of tree spacing and height reduction on cone production in two Douglas-fir seed orchards. West J Appl For, 9(1):5-7.

- Funda, T., Y. El-Kassaby, 2012: Seed orchard genetics. CAB Reviews Perspectives in Agriculture Veterinary Science Nutrition and Natural Resources, 7 (13):1-23.

- Gerwig, D.M., 1987: Annual top pruning as a crown management technique in youngloblolly pine seed orchard to reduce height and still produce flowers. In: Proc. 19th Southern For. Tree Imp. Conf.:208-215.

- Greenwood M.S., D.L. Bramlett, 1989: Effects of crown pruning on height and cone productionby loblolly pine after 6 years. In: Proc. 19th Southern For. Tree Imp. Conf. :130-134.

- Kang, K.S. 2001: Genetic gain and gene diversity of seed orchard crops. Doctor's Dissertation. Printed by SLU, Grafiska Enheten, Umea, Sweden.

- Kajba, D., N. Pavičić, S. Bogdan, I. Katičić, 2007: Pomotechnical treatments in the broadleave clonal seed orchards. Sumarski List, 11-12: 523-528.

- Kolpak, S.E., J. Smith, M.J. Albrecht, J. DeBell, S. Lipow, M.L. Cherry, G.T. Howe, 2015: High-density miniaturized seed orchards of Douglas-fir. New Forests, 46:121-140.

- Koski, V., J. Antola, 1993: Turkish National Tree Breeding and Seed Production Program for Turkey (1994-2003), Cooprepared with ENSO Forest Development Inc and Forest Tree Seeds and Tree Breeding Institute, Ankara, $49 \mathrm{p}$.

- Miller, L.K., J. DeBell, 2013: Current seed orchard techniques and innovations. USDA Forest Service Proceedings, RMRSP-69:80-86.
- Matheson, A.C., K.W. Willcocks, 1976: Seed yield in a radiata pine seed orchard following pollarding. N.Z. J. For. Sci. 6 (1): 14-18.

- Matziris, D., 1997: Variation in growth, flowering and cone production in a clonal seed orchard of Aleppo pine grown in Greece. Silvae Genetica, 46: 224-228.

- Nienstaedt, H., 1981: Top pruning white spruce seed orchard grafts. Tree Planters' Notes, 32(2): 19-13.

- Oatiam., 2015: Forest Tree Seeds and Tree Breeding Research Direcorate http://ortohum.ogm.gov.tr/SitePages/OGM/OGMDefault.aspx (24 August, date last accesed).

- Ozturk, H., S. Seref, S. Keskin, F. Topcuoglu, M. Sahin, M. Alan, B. Korkmaz, A. Karadeniz, 2005: The effect of endogenous growth hormone level, banding with wire and stem injection of Gibberelline A4/7/9 on the flowering in a Turkish red pine (Pinus brutia Ten.) seed orchard. Orman Ağaçları ve Tohumları Islah Araştırma Müdürlüğü Yayınları Teknik Bülten Serisi No: 14 (in Turkish with English abstract).

- Ross, S.D., 1989: Long term cone production and growth responses to crown management and gibberellin A4/7 treatment in a young western hemlock seed orchard. New Forest, 3:235245.

- SAS Institute Inc., 2002: SAS/STAT Users' Guide. SAS Institute, Cary, NC, USA.

- Sengun, S., H. Semerci, 2002: The effects of top pruning on flower and cone production in a Turkish red pine (Pinus brutia Ten.) clone park established in Antalya, Düzlerçamı in Turkey. Orman Ağaçları ve Tohumları Islah Araştırma Müdürlüğü Teknik Bülten Serisi No: 8 (in Turkish with English abstract).

- Smith, R., 2004: Crown management in conifer seed orchards. In: L. Ferguson (eds), Proceedings $31^{\text {st }}$ Annual Meeting Plant Growth Regulation Society of America (PGRSA) : 71-75.

- Stoehr, M., C. Hollefreund, J. Webber, C. Hewsonz, S. Ross, 1995: Effects of crown-pruning on seed and pollen cone production in two lodgepole pine seed orchards in British Columbia. New Forests, 10: 133-143.

- Sweet, G.B., 1975: Flowering and seed production. In: R. Faulkner (eds), Seed Orchards. Forestry Commission Bulletin 54, pp 72-82.

- Urgenc, S., 1967: Researches on some problems which were based to supply seeds of pines in Turkey (Türkiye'de çam türlerinde tohum tedarikine esas teşkil eden problemlere ait araştırmalar). Orman Genel Müdürlüğü Yayın Sıra No:468, Seri No:44, 192 s. (in Turkish).

- Webber, J. C. Hewson, C. Walsh, G. Giampa, 2003: Western larch crown pruning methods. Forest Genetics Council of British Columbia, TICtalk 5: 17-19.

\section{Sažetak}

U ekonomskom i biološkom smislu (brzi rast, vrlo rana sposobnost proizvodnje sjemena, itd.), Pinus brutia Ten. jedna je od najvažnijih vrsta šumskog drveća u Turskoj. Postignut je značajan napredak u uzgoju Pinus brutia Ten. u Turskoj te su razvijene sjemenske plantaže na 615 hektara površine, fenotipski i prema rezultatima ispitivanja polusrodnika. Područje koje zauzimaju sjemenske plantaže Pinus brutia Ten., koji pokriva najveće područje od svih vrsta, iznosi 43 \% ukupne površine sjemenskih plantaža. 
Kako bi se prikupili podaci o upravljanju sjemenskim plantažama, izvršeno je prikraćivanje krošnje na trima sjemenskim plantažama Pinus brutia Ten. različite dobi (starim, srednjim i mladim). Dva su režima prikraćivanja primijenjena na ovim trima sjemenskim plantažama, jednom 2008. godine u starijoj plantaži, dok je jedan režim ovršivanja primijenjen 2008. i 2012. godine na srednjoj i mladoj plantaži. Svake su godine mjereni visina, prsni promjer te promjer krošnje u dva smjera te su izbrojani svi češerčići i češeri na rametama tijekom i nakon rezidbe.

Po isteku četiri godine, indeks visine, prsnog promjera i volumena povećao se kod kontrolnih rameta u starim i mladim sjemenskim plantažama u usporedbi s plantažom srednje dobi. S druge strane, iako su kontrolne ramete u plantažama srednje dobi dosegle veću visinu, rezane ramete dosegle su veći indeks volumena i prsnog promjera. Dok su se na početku primijećene razlike u visini između kontrolnih i rezanih rameta u svim sjemenskim plantažama postupno smanjile, primijećeno je da su visine rezanih rameta bile proporcionalno veće.

Između kontrolnih i rezanih rameta nije bilo razlike u smislu uroda češerčića i češera. Intervali i režimi prikraćivanja varirali su u starim, srednjim i mladim plantažama, te se uočilo da bi se prikraćivanje moglo koristiti u starim, srednjim i mladim sjemenskim plantažama.

KLJUČNE RIJEČI: brucijski crveni bor, uzgoj, proizvodnja sjemenja, upravljanje sjemenskom plantažom, pošumljavanje 